Irena Selišnik

\title{
MATJAŽ URŠIČ IN MARJAN HOČEVAR: PROTIURBANOST KOT NAČIN ŽIVLJENJA.
}

Liubljana: Fakulteta za družbene vede, 2007, Knjižna zbirka Ost, 128 strani.

Avtorja Matjaž Uršič in Marjan Hočevar se v knjigi Protiurbanost kot način življenja lotevata dekonstrukcije želje povprečnega Slovenca ali Slovenke, hišica $\mathrm{z}$ vrtom, na samem, a vendar dovolj blizu mesta. To težnjo interpretirata kot izraz izbire življenjskega stila Slovencev, ki ga zaznamuje proti-urbanost, katera pa je rezultat kompleksnih procesov v družbi, ki so v tekstu podrobneje in zanimivo predstavljeni. Čeprav je študija namenjena analizi trendov $\mathrm{v}$ urbanizmu, pa ta namen preseže in spregovori o značilnostih sodobne slovenske družbe. Poglobljena analiza je tako namenjena najširšemu krogu bralcev, še zlasti pa bi morala postati obvezno čtivo vseh, ki se ukvarjajo s prostorskim planiranjem in dolgoročnim razvojem Slovenije.

V monografiji so tako sprva predstavljena teoretska izhodišča študije, koncepti, na katerih se bodo kasneje v knjigi oprla konkretna dognanja o slovenski družbi. V središču se tako nahaja koncept urbanosti, ki pa ni več vezan na prostor, pač pa na način življenja. Uporaba in izraba prednosti in možnosti, ki jih ponuja mesto in posledično identifikacijsko pomestenje, ni več vezano izključno na kraj bivanja. Procesi uveljavljanja komunikacijskih in transportnih tehnologij naj bi krčili dihotomijo mesto-vas. Kljub fizični oddaljenosti od mesta tako lahko ljudje živijo urbani način življenja in obratno, kljub fizični prisotnosti $\mathrm{v}$ mestu lahko ljudje zavračajo urbani način življenja. Avtorja tako predpostavljata, da povečevanje dostopnosti $\mathrm{v}$ prostoru potencialno omogoča posameznikom in skupinam večjo izbiro življenjskega stila, bodisi urbanosti ali suburbanosti.

Tudi v Sloveniji se tako trenutno dogaja homogenizacija (nerazločljivost) družbeno-prostorsko enot, ki pa ima posebne specifike, ki so rezultat posebnega razvoja družbe. $\mathrm{V}$ nadaljevanju monografije poglavja 
dajejo uvid v razloge za specifični značaj slovenske urbanizacije, ki je potekala znatno počasneje kot $\mathrm{v}$ primerljivih državah $\mathrm{v}$ istem obdobju. V slovenski urbanizaciji je umanjkala metropolizacija, ki jo je nadomestil koncept policentričnega urbanega razvoja in industrializacija podeželja. Za urbanizacijo Slovenije je tako značilen razpršen vzorec poselitve in bistveno manjša urbana področja, zaznamovala pa jo je tudi odsotnost velikega mesta. Te značilnosti slovenskega procesa urbanizacije pa so vplivale tudi na vzorce življenja in bivanja.

V poglavju Geneza slovenske poti urbanosti se tako avtorja lotevata ne le materialističnih razlogov za prostorski razvoj Slovenije, pač pa tudi kulturnih. Po krajšem pregledu razlogov za današnje prostorsko stanje, kot so slaba "podlaga « za razvoj industrije in periferna pozicija slovenskega prostora pred drugo svetovno vojno, sledi bolj izčrpna obravnava posebnosti urbanizacije po drugi svetovni vojni. Avtorja tako Slovenijo postavljata $\mathrm{v}$ širši referenčni okvir urbanističnih politik ostalih socialističnih držav, da bi prikazala slovenske specifike. Tudi drugod so različni ukrepi zmanjšali potenciale razvoja mest in mestnega načina življenja, toda samo na Slovenskem je izstopalo izredno počasno naraščanje mestnega prebivalstva. Kljub intenzivni deagrarizaciji je velik del prebivalstva še vedno ostal na podeželju. $\mathrm{K}$ temu je pripomogla težka dostopnost do stanovanj v mestih, ki je imela za posledico gradnjo velikih stanovanjskih hiš na lastnih zemljiščih na podeželju, saj so ta bila lažje dosegljiva. Poleg tega je prebivalstvo našlo dodaten vir dohodka $\mathrm{v}$ stranskih (agrarnih) dejavnostih. V populaciji je nastal suburbani presežek, torej razlika med velikim številom delovnih mest $\mathrm{v}$ industriji in majhnim deležem mestnega prebivalstva. Posledično imamo tako Slovenci glede na evropske razmere nadpovprečno velike stavbne parcele $\mathrm{z}$ velikimi samostojno stoječimi hišami, v katerih je relativno malo stanovalcev, in razpršen vzorec poselitve, ki za seboj potegne tudi visoke stroške komunalne in komunikacijske infrastrukture. Tu samopodoba Slovencev kot varčnega in skromnega naroda odpove.

$\mathrm{V}$ istem sklopu so tako predstavljeni tudi vrednostni protiurbani vzorci prebivalstva, ki bi si mogoče zaslužili posebno poglavje. Vrednostne orientacije prebivalstva na Slovenskem, usmerjene $\mathrm{k}$ kulturnem izolacionizmu in zaščiti slovenstva 
proti tujim, neslovenskim elementom, avtorja povezujeta $\mathrm{z}$ domačijsko naravnano nacionalno ideologijo. Glede prostorskih praks je tako opazna kulturna identifikacija slovenstva s podeželjem, medtem ko naj bi mesta bila percepirana kot tujek in tudi grožnja slovenskemu načinu življenju. Tudi mestno prebivalstvo naj bi ne bilo izvzeto iz tovrstne identifikacije in naj bi si nostalgično želelo vrnitve nazaj, nazaj $\mathrm{k}$ naravi, nazaj v varno idilo.

$\mathrm{V}$ nadaljevanju knjige avtorja bolj podrobneje na podlagi podatkov iz različnih javnomnenjskih anket analizirata značilnosti te nostalgične želje. Prebivalstvo prestolnice tako povsem zavrača tiste novosti, ki naj bi bile odlike velikih mest, npr. nočno življenje. V željah večine naj bi se kazale protislovne težnje Slovencev in Slovenk, ki naj bi jih zaznamoval slovenski tip avtarkičnega individualizma. Ti/e nasprotujejo novostim, ki bi spremenile njihovo neposredno okolice, čeprav bi bile sicer koristne za skupnost. Tako zavračajo tudi izrabo kmetijskih zemljišč za gradnjo naselij, hkrati pa si ne želijo živeti v strnjenih stanovanjskih soseskah.

$\mathrm{V}$ predzadnjem poglavju, ki mu sledi le še sklepna beseda, avtorja postavljata pod drobnogled še ne- katere izmed formalno nezaželenih prostorskih procesov, ki so vezani na protiurbane prostorske vrednosti in so prisotni v sodobni slovenski družbi. Na procese suburbanizacije so tako po osamosvojitvi Slovenije začeli vplivati novi dejavniki, kot je individualizacija transportnih sredstev, nerazvitost trga nepremičnin ali visoke cene zemljišč $\mathrm{v}$ mestih. Slovenska suburbanizacija je posledično prerasla $v$ večfaktorsko suburbanizacijo, za katero je značilno, da se iz mest ne selijo več le posamezniki, pač pa tudi gospodarska dejavnost. Avtorja ne ponujata rešitev, kako preseči soobstoj materialnih in ideoloških struktur, ki povzročajo skupni učinek suburbanizacije, nam pa prikažeta kompleksnost slednje problematike in tako opozorita na nekatere nezadovoljive odgovore, kot je ideološka konstrukcija urbanosti za potrebe turizma ali kulturne potrošnje, ki ni orientirana na zadovoljevanje potreb lokalnega prebivalstva, ki živi v mestnih središčih.

Avtorja tako razkrivata kar nekaj paradoksov slovenske družbe, ki se kažejo v protislovnih željah Slovencev in Slovenk in ki popolnoma zanemarjajo eksternalije ali lantentne stroške. Ti se ne odražajo le v ceni dobrine, pač pa vplivajo na blagostanje celotne skupnosti in 
brez njihovega upoštevanja, bo dol- Tako ekonomsko naravnani ukrepi goročen razvoj slovenske družbe še za investicije $\mathrm{v}$ novo infrastrukturo naprej peljal v degradacijo mestnih ali priprava novih strategij prostorsredišč in slabšo kakovost življenja skega razvoja ne zadoščajo, saj je nasploh. S prenosljivimi vzorci bi- potrebno imeti tudi mehanizme za vanja in življenja, ki so nastali to- spremembo negativnih stališč do žikom zgodovinskega razvoja, in se vljenja v mestu oziroma preseganje odražajo v vseh prostorskih in so- protiurbane ideologije. Marsikatero ciokulturnih spremembah, pa kaže ugotovitev te pronicljive študije bi se previdno ravnati, na kar v sklepnem tako lahko apliciralo na prenekatero poglavju opozarjata tudi avtorja. področje družbenega življenja. 